\section{Comparative Physiological Analysis of Salinity Effects in Six Olive Genotypes}

\author{
Carolina Aparicio \\ Department of Animal Biology, Plant Biology and Ecology, University of \\ Jaen, Jaen, Spain
}

Miguel Urrestarazu

Centro de Investigación BITAL, University of Almeria, E-04120, Almeria, Spain

\author{
María del Pilar Cordovilla ${ }^{1}$ \\ Department of Animal Biology, Plant Biology and Ecology, University of \\ Jaen, Jaen, Spain
}

Additional index words. compatible solutes, Olea europaea, potassium content, sodium content, total phenol

\begin{abstract}
Changes caused by $\mathrm{NaCl}$ salinity on growth, gas exchange, chemical composition, and oxidative stress symptoms have been measured in six olive (Olea europaea $\mathrm{L}$.) cultivars (Casta Cabra, Cornicabra, Frantoio, Ocal, Picual, and Picudo) grown in nutrient solution in a growth chamber pot experiment. Six-month-old plants were transplanted to a sand-perlite culture and irrigated with half-strength Hoagland nutrient solution containing 0 and $200 \mathrm{~mm} \mathrm{NaCl}$ for 12 weeks. Salinity significantly depressed growth and leaf gas exchange, but to a different degree in each cultivar, Picudo was the cultivar that showed less growth inhibition. The effectiveness of $\mathrm{Na}^{+}$exclusion mechanism in the roots differed significantly among studied cultivars, working effectively in 'Ocal' and 'Picudo' and being less efficient in 'Picual'. Furthermore, 'Picudo' showed the ability to maintain the concentration of leaf $\mathrm{K}^{+}$under the stress condition. 'Ocal' accumulated phenolic compounds and did not reduce carotenoid or total thiol concentration under saline stress. Between the cultivars studied, 'Picudo' and 'Ocal' were the most tolerant.
\end{abstract}

In the Mediterranean region, the olive is considered to be the most important fruit tree in the area (International Olive Oil Council, 2003). In this region, olive tree cultivation is being extended to irrigated land where salinity is becoming a major problem as a result of a high rate of evaporation and insufficient leaching (Calero et al., 2013; Chartzoulakis, 2005). In addition, water scarcity in the Mediterranean basin restricts the availability of fresh water for crop irrigation. To overcome water shortages and to satisfy the increasing water demand for agricultural development, the use of saline water may become an unavoidable necessity.

Olive is considered moderately tolerant to salinity (Demiral, 2005), although the response of plants to saline stress is a genotypicdependent characteristic (Chartzoulakis et al., 2002; Weissbein et al., 2008). The olive tree's ability to acclimate to saline stress includes morphological, anatomical, and physiological alterations at the leaf level (Tattini et al., 1995). However, tolerance to $\mathrm{NaCl}$ in olive is mostly related to the salt exclusion mechanism at the root level, which prevents sodium $\left(\mathrm{Na}^{+}\right)$accumulation in leaf tissue as well as the ability of the olive to maintain an essential

Received for publication 13 May 2014. Accepted for publication 25 May 2014.

${ }^{1}$ To whom reprint requests should be addressed; e-mailmpilar@ujaen.es. the leading decisive factors to carry out this research. In fact, olive plants of less than 1 year in the nurseries could be irrigated with saline water to help overcome water shortages. Therefore, the main aim of this study is to compare the salinity tolerance of six olive genotypes of great socioeconomic importance in the Mediterranean region. In an effort to elucidate the adaptive strategies of young olive plants to salinity salt accumulation $\left(\mathrm{Na}^{+}, \mathrm{K}^{+}\right)$in roots and leaves, leaf concentration of photosynthetic pigments (chlorophylls, carotenoids), free amino acids, free proline, total soluble carbohydrates, total phenols, and total thiols were measured. Also, the effects of salinity on growth and gas exchange rates [net $\mathrm{CO}_{2}$ assimilation rate and stomatal conductance $\left.\left(g_{\mathrm{S}}\right)\right]$ were assessed.

\section{Materials and Methods}

Plant material and growth conditions. This study was conducted with five autochthonous Spanish cultivars (Casta Cabra, Cornicabra, Ocal, Picual, and Picudo) and one Italian cultivar (Frantoio). Uniform, 6-month-old rooted plants (Viveros Laserplant CB, Córdoba, Spain) were transplanted to $1.5-\mathrm{L}$ pots containing a sand-perlite mixture $(1: 3, \mathrm{v} / \mathrm{v})$. Plants were well established by watering three times per week with $100 \mathrm{~mL}$ of half-strength Hoagland's solution (Hoagland and Arnon, 1950). After 4 weeks, salt treatments were started by daily applying $25 \mathrm{~mm} \mathrm{NaCl}$ in the nutrient solution to reach the final $\mathrm{NaCl}$ concentration of $200 \mathrm{~mm}$, whereas the salt-free control plant $(0 \mathrm{~mm})$ continued to receive only nutrient solution. The salinity treatments lasted 12 weeks, the experiment ending when the plants were 10 months old. The experimental design was a six $\times$ two factorial (six cultivars $\times$ two salt treatments) with six replicate plants in each treatment using a complete random design in a growth chamber with a 16-8-h light-dark cycle, 25 to $20{ }^{\circ} \mathrm{C}$ day-night temperature, relative humidity $55 \%$ to $75 \%$, and photosynthetic photon flux density (400 to $700 \mathrm{~nm})$ of $500 \mu \mathrm{mol} \cdot \mathrm{m}^{-2} \cdot \mathrm{s}^{-1}$.

Plant growth and leaf parameters. At the end of the experiment, all plants were gently removed from the substrate, roots were washed with distilled water, and partitioned into different organs. After the measurement of fresh weight, shoot length, and total leaf area (LA) of each plant, roots, stems, and leaves were dried at $65^{\circ} \mathrm{C}$ for $72 \mathrm{~h}$ in a forced-air oven and the dry weight (DW) was determined. LA was determined using the method established by Tattini et al. (1995). The area of each leaf was calculated according to the following regressions equations: Munns and Tester, 2008). Moreover, it has been reported that proline protects higher plants against osmotic stress not only by facilitating the retention of water in the cytoplasm, but also by functioning as an oxygen radical scavenger and by displaying an antioxidant activity (Iqbal et al., 2014).

The fresh water scarcity in the Mediterranean basin for crop irrigation, the socioeconomic importance of cultivation olive, and the lack of studies comparing olive cultivars of less than a year in controlled conditions were

$$
\begin{aligned}
& \text { For 'Casta Cabra': } \\
& \quad \mathrm{Y}=0.695 \mathrm{X}+0.139\left(r^{2}=0.980\right) \\
& \text { For 'Cornicabra': } \\
& \quad \mathrm{Y}=0.732 \mathrm{X}-0.061\left(r^{2}=0.984\right) \\
& \text { For 'Frantoio': } \\
& \quad \mathrm{Y}=0.641 \mathrm{X}+0.383\left(r^{2}=0.986\right)
\end{aligned}
$$


For 'Ocal':

$$
\mathrm{Y}=0.662 \mathrm{X}+0.257\left(r^{2}=0.978\right)
$$

For 'Picual':

$$
\mathrm{Y}=0.639 \mathrm{X}+0.304\left(r^{2}=0.987\right)
$$

For 'Picudo':

$$
\mathrm{Y}=0.688 \mathrm{X}+0.014\left(r^{2}=0.986\right)
$$

where $\mathrm{Y}$ is leaf area and $\mathrm{X}$ is the product length $\times$ width.

The concentrations of $\mathrm{Na}^{+}$and $\mathrm{K}^{+}$in leaf and root were measured with an emission-absorption spectrophotometer (Perkin Elmer AAnalyst $800)$ after the tissue had been dry-ashed for $24 \mathrm{~h}$ at $450{ }^{\circ} \mathrm{C}$ and suspended in $37 \% \mathrm{HCl}$.

Biochemical analysis. Net $\mathrm{CO}_{2}$ assimilation rate $\left(P_{\mathrm{n}}\right)$ and $g_{\mathrm{S}}$ were measured at saturating light photosynthetically active radiation greater than $800 \mu \mathrm{mol} \cdot \mathrm{m}^{-2} \cdot \mathrm{s}^{-1}$ ) on the youngest fully expanded leaves of six plants per treatment using a portable photosynthesis system (LI-COR 6400; LI-COR Inc., Lincoln, NE). Measurements were made between 1 and $4 \mathrm{~h}$ after the beginning of the photoperiod. Leaf sections were homogenized in $80 \%$ acetone (Arnon, 1949) for chlorophyll (Chl),

Table 1. Effects of salinity ( 0 or $200 \mathrm{~mm} \mathrm{NaCl})$ on shoot length, total dry weight $(\mathrm{DW})$, root/shoot ratio $(\mathrm{Rt} / \mathrm{Sh})$, leaf area $(\mathrm{LA}), \mathrm{CO}_{2}$ assimilation rate $\left(P_{\mathrm{n}}\right)$, stomatal conductance $\left(g_{\mathrm{S}}\right)$, and photosynthetic pigments of six olive cultivars 12 weeks after saline treatments started. ${ }^{z}$

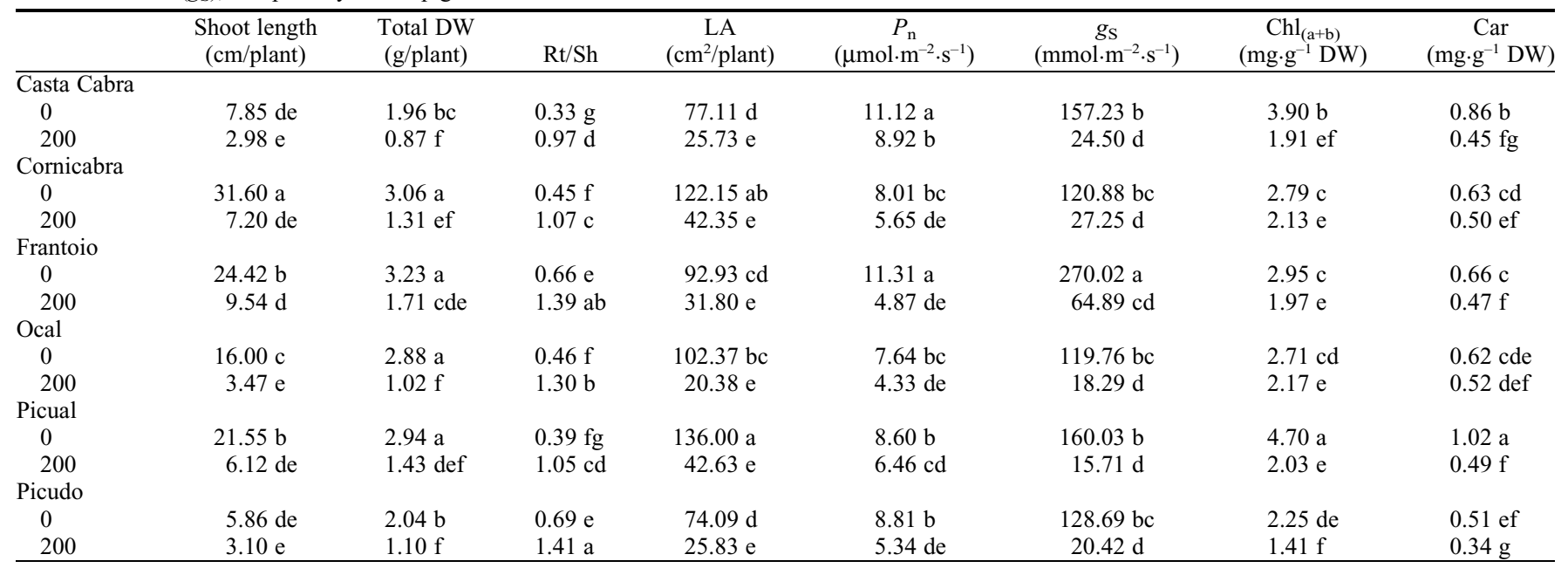

${ }^{\mathrm{z}}$ Values are mean of six replicates for shoot length, total DW, Rt/Sh, LA, $P_{\mathrm{n}}$, and $g_{\mathrm{S}}$, and four replicates for photosynthetic pigments. Within each column, means followed by the same letters are not significantly different at $5 \%$.

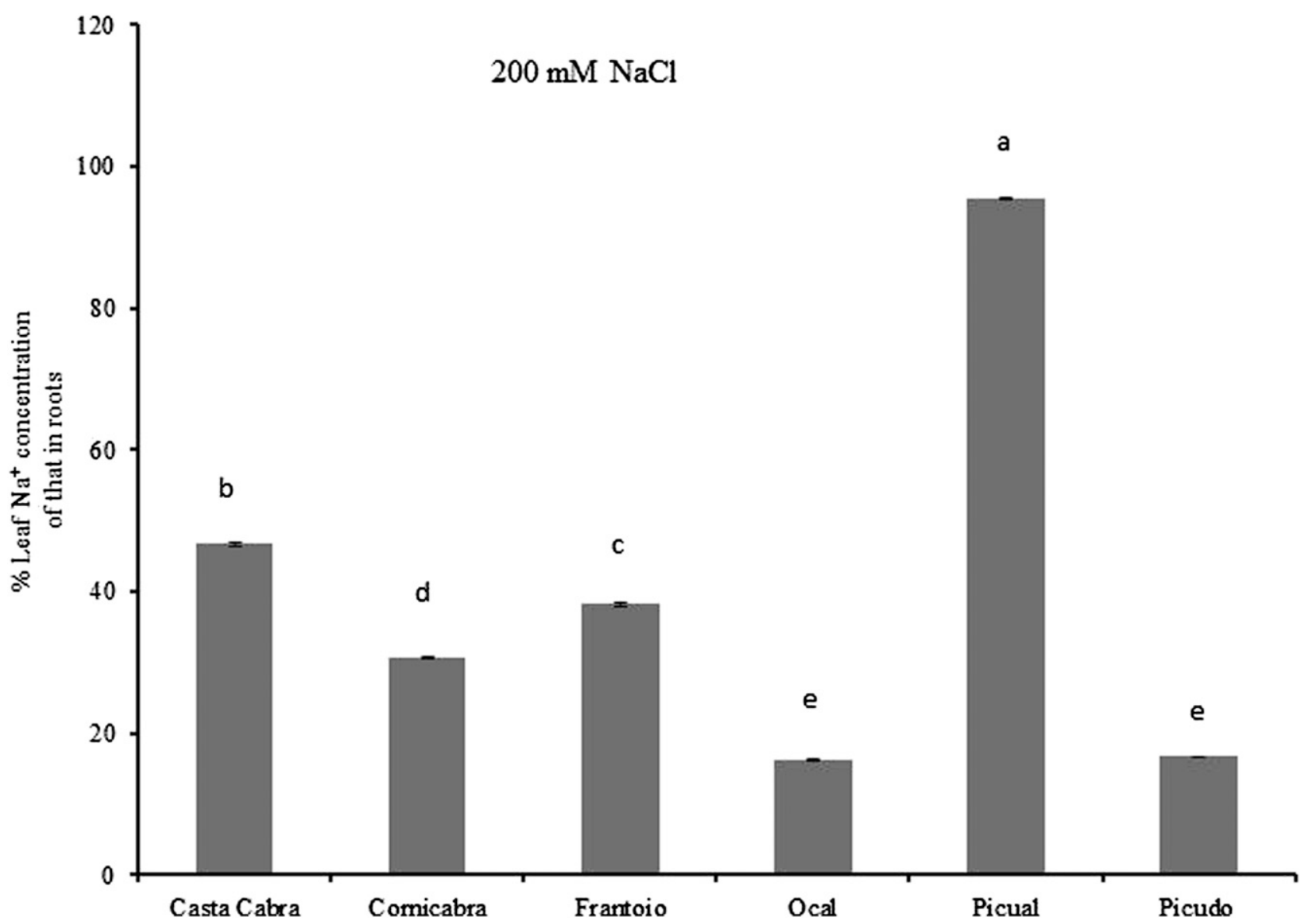

Fig. 1. Percentage of leaf sodium $\left(\mathrm{Na}^{+}\right)$concentration (percent dry weight) as compared with root sodium $\left(\mathrm{Na}^{+}\right)$concentration (percent dry weight) at 200 mM $\mathrm{NaCl}$ in the six cultivars investigated. Values are mean of three replicates. Bars marked with the same letter were not significantly different at $5 \%$. 
carotenoid, and phenol determination (Singleton and Rossi, 1965; Wellburn, 1994). Carbohydrate content was measured as described by Irigoyen et al. (1992). Free proline was quantified according to Bates et al. (1973) and free amino acids were estimated by using the method of Rosen (1957). Total thiol content (-SH) was assayed according to Ellman (1959) using 5,5' -dithiobis (2-nitrobenzoic acid).

Statistical analysis. All data were subjected to a two-way analysis of variance (effects of cultivar and $\mathrm{NaCl}$ treatments as fixed factors with its interaction factor). Significantly different means were compared using Tukey's test $(P<0.05)$. All calculations, including statistical analysis, were computed using IBM SPSS Statistics 19 (SPSS Inc., Chicago, IL).

\section{Results and Discussion}

Plant growth, leaf characteristics, and tissue mineral content. The largest reduction in shoot length, total DW, and LA caused by salinity was detected in 'Ocal' $(78 \%, 65 \%$, and $80 \%$, respectively) (Table 1 ). In contrast, shoot length was unaffected in 'Picudo' and 'Casta Cabra'. Furthermore, 'Picudo' showed the lowest inhibition in total DW and LA (46\% and 65\%, respectively) and the lowest increase in root/shoot (2.04-fold). However, according to Chartzoulakis (2005), salt tolerance in olive cultivars is associated with the effective mechanisms of ion exclusion and retention of saline ions in the root. In this regard, $\mathrm{Na}^{+}$concentration in salinized plants increased more in the leaf than in roots in 'Cornicabra', 'Picual', 'Frantoio', and 'Casta Cabra' (21-fold), whereas in 'Ocal' and 'Picudo', $\mathrm{Na}^{+}$concentration increased more in roots than in leaf. In addition, according to leaf $\mathrm{Na}^{+}$concentration of that in root (Fig. 1), studied cultivars can be divided into three groups. The first one includes 'Picual', which showed similar concentration of $\mathrm{Na}^{+}$in root and leaf. The second group includes cultivars that accumulated $\mathrm{Na}^{+}$at high concentrations in root but increased $\mathrm{Na}^{+}$concentration more in leaf than in root (Table 2). These cultivars are Casta Cabra, Cornicabra, and Frantoio, which showed a leaf $\mathrm{Na}^{+}$concentration of $47 \%, 31 \%$, and $38 \%$ of that in root, respectively. The third group includes 'Ocal' and 'Picudo', which are characterized by an important accumulation of $\mathrm{Na}^{+}$in root and an important inhibition of translocation of this element to leaf. Therefore, among cultivars studied, 'Picudo' and 'Ocal' were the most salt-tolerant.

Under saline condition, the $\mathrm{K}^{+}$concentration decreased in roots of all cultivars with 'Picudo' (46\%) and 'Ocal' (50\%) showing the lowest decrease (Table 2). In leaf, the strongest inhibition was detected in 'Picual' (51\%), whereas 'Picudo' was unaffected. In addition, 'Ocal' and 'Picudo' showed the lowest decrease of $\mathrm{K}^{+} / \mathrm{Na}^{+}$in leaf $(88 \%)$, whereas 'Picual' registered the highest $(98 \%)$. High leaf $\mathrm{K}^{+}$concentration facilitates osmotic adjustment with relatively less energy expenditure than the accumulation of other compatible solutes like mannitol and glucose in olive trees (Tattini et al., 1995).
Leaf gas exchange parameters. $P_{\mathrm{n}}$ and $g_{\mathrm{S}}$ sharply declined in response to salinity (Table 1). The drop in $g_{\mathrm{s}}$ under saline stress may be an adaptive response to decreased water content. In this regard, Loreto et al. (2003) indicated that photosynthesis was indirectly limited by the lower water availability in salt-stressed olive trees with different sensitivity to salt stress. In addition, photosynthesis could be limited by non-optimal metabolic conditions caused by $\mathrm{Na}^{+}$accumulation (Table 2). Similar results were reported by Kchaou et al. (2013) for other olive cultivars.

Photosynthetic pigments and metabolites in leaves. Cultivar Ocal did not significantly inhibit carotenoid content by salinity (Table 1). It has been well documented that carotenoids are involved in the protection of the photosynthetic apparatus against photoinhibitory damage by singlet oxygen, which is produced

by the excited triplet state of chlorophyll (Yazici et al., 2008). In fact, 'Ocal' was the cultivar that showed the lowest reduction in $\mathrm{Chl}_{(\mathrm{a}+\mathrm{b})}$ content $(20 \%)$. In contrast, 'Picual' showed the sharpest reduction in the carotenoid and $\mathrm{Chl}_{(\mathrm{a}+\mathrm{b})}$ contents.

Salinity induced a decrease in total thiol concentration in 'Casta Cabra' (34\%), 'Picual' (27\%), 'Picudo' (22\%), and 'Frantoio' (11\%) (Table 3), probably as a result of the oxidation of non-protein -SH groups. Oxidative stress depletion on non-protein thiols enhances the susceptibility to membrane damage by lipid peroxidation and may trigger ROS irreversible negative effects on cellular function (Ali et al., 2005).

The soluble carbohydrate, amino acids, and proline in leaves were not increased by salinity in any cultivars (Table 3 ). In contrast, Ben Ahmed et al. (2011) reported proline accumulation by salinity in plants of 2 years

Table 2. Effects of salinity $(0$ or $200 \mathrm{~mm} \mathrm{NaCl})$ on sodium $\left(\mathrm{Na}^{+}\right)$and potassium $\left(\mathrm{K}^{+}\right)$content in leaf and root of six olive cultivars 12 weeks after saline treatments started. ${ }^{2}$

\begin{tabular}{|c|c|c|c|c|c|c|}
\hline & \multicolumn{3}{|c|}{ Leaf (\%) } & \multicolumn{3}{|c|}{ Root (\%) } \\
\hline & $\mathrm{Na}^{+}$ & $\mathrm{K}^{+}$ & $\mathrm{K}^{+} / \mathrm{Na}^{+}$ & $\mathrm{Na}^{+}$ & $\mathrm{K}^{+}$ & $\mathrm{K}^{+} / \mathrm{Na}^{+}$ \\
\hline \multicolumn{7}{|c|}{ Casta Cabra } \\
\hline 0 & $0.08 \mathrm{gh}$ & $1.96 \mathrm{a}$ & $25.76 \mathrm{c}$ & $0.75 \mathrm{f}$ & $1.69 \mathrm{c}$ & $2.25 \mathrm{~d}$ \\
\hline 200 & $1.67 \mathrm{~b}$ & $1.36 \mathrm{e}$ & $0.81 \mathrm{f}$ & $3.58 \mathrm{~b}$ & $0.44 \mathrm{~g}$ & $0.12 \mathrm{e}$ \\
\hline \multicolumn{7}{|c|}{ Cornicabra } \\
\hline 0 & $0.03 \mathrm{i}$ & $1.38 \mathrm{de}$ & $50.37 \mathrm{a}$ & $0.81 \mathrm{e}$ & $3.58 \mathrm{a}$ & $4.39 \mathrm{~b}$ \\
\hline 200 & $1.11 \mathrm{c}$ & $1.01 \mathrm{f}$ & $1.10 \mathrm{f}$ & $3.63 \mathrm{~b}$ & $0.57 \mathrm{f}$ & $0.16 \mathrm{e}$ \\
\hline \multicolumn{7}{|c|}{ Frantoio } \\
\hline 0 & $0.04 \mathrm{i}$ & $1.47 \mathrm{c}$ & $34.04 \mathrm{~b}$ & $0.46 \mathrm{~g}$ & $1.54 \mathrm{~d}$ & $3.36 \mathrm{c}$ \\
\hline 200 & $1.04 \mathrm{~d}$ & $1.22 \mathrm{f}$ & $1.17 \mathrm{f}$ & $2.73 \mathrm{~d}$ & $0.61 \mathrm{f}$ & $0.22 \mathrm{e}$ \\
\hline \multicolumn{7}{|l|}{ Ocal } \\
\hline 0 & $0.07 \mathrm{~h}$ & $1.38 \mathrm{de}$ & $19.76 \mathrm{~d}$ & $0.15 \mathrm{i}$ & $0.84 \mathrm{e}$ & $5.45 \mathrm{a}$ \\
\hline 200 & $0.53 \mathrm{f}$ & $1.23 \mathrm{f}$ & $2.30 \mathrm{f}$ & $3.28 \mathrm{c}$ & $0.42 \mathrm{~g}$ & $0.13 \mathrm{e}$ \\
\hline \multicolumn{7}{|l|}{ Picual } \\
\hline 0 & $0.09 \mathrm{gh}$ & $1.52 \mathrm{~b}$ & $17.35 \mathrm{de}$ & $0.38 \mathrm{~h}$ & $2.06 \mathrm{~b}$ & $5.37 \mathrm{a}$ \\
\hline 200 & $2.62 \mathrm{a}$ & $0.75 \mathrm{~g}$ & $0.29 \mathrm{f}$ & $2.74 \mathrm{~d}$ & $0.82 \mathrm{e}$ & $0.30 \mathrm{e}$ \\
\hline \multicolumn{7}{|l|}{ Picudo } \\
\hline 0 & $0.09 \mathrm{~g}$ & $1.42 \mathrm{~cd}$ & $15.02 \mathrm{e}$ & $0.39 \mathrm{~h}$ & $1.67 \mathrm{c}$ & $4.21 \mathrm{~b}$ \\
\hline 200 & $0.84 \mathrm{e}$ & $1.43 \mathrm{c}$ & $1.70 \mathrm{f}$ & $5.03 \mathrm{a}$ & $0.90 \mathrm{e}$ & $0.18 \mathrm{e}$ \\
\hline
\end{tabular}

${ }^{2}$ Values are mean of three replicates. Within each column, means followed by the same letters are not significantly different at $5 \%$.

Table 3. Effects of salinity ( 0 or $200 \mathrm{~mm} \mathrm{NaCl}$ ) on soluble carbohydrates, free proline, free amino acids, total phenol, and total thiol concentrations of leaf of six olive cultivars 12 weeks after saline treatments started. ${ }^{z}$

\begin{tabular}{|c|c|c|c|c|c|}
\hline & $\begin{array}{l}\text { Soluble carbohydrates } \\
\left(\mathrm{mg} \cdot \mathrm{g}^{-1} \mathrm{DW}\right)\end{array}$ & $\begin{array}{c}\text { Proline } \\
\left(\mu \mathrm{g} \cdot \mathrm{g}^{-1} \mathrm{DW}\right)\end{array}$ & $\begin{array}{l}\text { Amino acids } \\
\left(\mu \mathrm{g} \cdot \mathrm{g}^{-1} \mathrm{DW}\right)\end{array}$ & $\begin{array}{l}\text { Total phenol } \\
\left(\mathrm{mg} \cdot \mathrm{g}^{-1} \mathrm{DW}\right)\end{array}$ & $\begin{array}{c}\text { Total thiol } \\
\left.\text { (nmol. } \mathrm{g}^{-1} \mathrm{DW}\right)\end{array}$ \\
\hline \multicolumn{6}{|c|}{ Casta Cabra } \\
\hline 0 & $28.21 \mathrm{cdef}$ & $81.71 \mathrm{abc}$ & $185.50 \mathrm{ab}$ & $24.79 \mathrm{f}$ & $172.04 \mathrm{a}$ \\
\hline 200 & $21.16 \mathrm{~g}$ & $47.25 \mathrm{de}$ & $146.92 \mathrm{def}$ & $19.93 \mathrm{~g}$ & $113.01 \mathrm{c}$ \\
\hline \multicolumn{6}{|c|}{ Cornicabra } \\
\hline 0 & $52.40 \mathrm{a}$ & $82.79 \mathrm{abc}$ & $175.38 \mathrm{abc}$ & $23.39 \mathrm{f}$ & $108.23 \mathrm{~d}$ \\
\hline 200 & $35.59 \mathrm{bcd}$ & $74.84 \mathrm{bc}$ & $119.57 \mathrm{fgh}$ & $25.08 \mathrm{f}$ & $108.04 \mathrm{~d}$ \\
\hline \multicolumn{6}{|c|}{ Frantoio } \\
\hline 0 & $25.76 \mathrm{fg}$ & $56.20 \mathrm{~cd}$ & $160.04 \mathrm{cde}$ & $32.55 \mathrm{~d}$ & $103.58 \mathrm{e}$ \\
\hline 200 & $25.71 \mathrm{fg}$ & $25.40 \mathrm{e}$ & $125.56 \mathrm{fg}$ & $41.37 \mathrm{a}$ & $92.59 \mathrm{~g}$ \\
\hline \multicolumn{6}{|l|}{ Ocal } \\
\hline 0 & $44.33 \mathrm{ab}$ & $64.42 \mathrm{~cd}$ & $99.68 \mathrm{gh}$ & $35.69 \mathrm{c}$ & $90.38 \mathrm{~g}$ \\
\hline 200 & $35.34 \mathrm{~cd}$ & $75.18 b c$ & $65.91 \mathrm{i}$ & $38.30 \mathrm{~b}$ & $92.55 \mathrm{~g}$ \\
\hline \multicolumn{6}{|l|}{ Picual } \\
\hline 0 & $31.61 \mathrm{cde}$ & $100.64 \mathrm{ab}$ & $198.63 \mathrm{a}$ & $14.67 \mathrm{~h}$ & $145.02 \mathrm{~b}$ \\
\hline 200 & $27.17 \mathrm{def}$ & $103.75 \mathrm{a}$ & 137.17 ef & $19.75 \mathrm{~g}$ & $105.40 \mathrm{de}$ \\
\hline \multicolumn{6}{|l|}{ Picudo } \\
\hline 0 & $36.84 \mathrm{bc}$ & $70.56 \mathrm{~cd}$ & $102.69 \mathrm{gh}$ & $33.96 \mathrm{~cd}$ & $96.86 \mathrm{f}$ \\
\hline 200 & $27.34 \mathrm{def}$ & $68.28 \mathrm{~cd}$ & $91.38 \mathrm{hi}$ & $28.28 \mathrm{e}$ & $75.61 \mathrm{~h}$ \\
\hline
\end{tabular}

${ }^{2}$ Values are mean of four replicates. Within each column, means followed by the same letters are not significantly different at $5 \%$.

$\mathrm{DW}=$ dry weight. 
of the salt-tolerant olive cultivar Chemlali. However, phenolic compound was increased in 'Picual' (34\%), 'Frantoio' (27\%), and 'Ocal' (7\%) (Table 3). This is important because phenolic compounds can act as compatible organic solutes and as molecular antioxidants through their ability to destroy free radicals (Blokhina et al., 2003). A similar result was described by Remorini et al. (2009) for the olive cultivar Cipressino.

In conclusion, between the cultivars studied, 'Picudo' and 'Ocal' were the most tolerant. Those cultivars showed the most effective mechanism of ion exclusion and retention of saline ions in the root. In addition, 'Picudo' and 'Ocal' showed an ability to maintain the most appropriate $\mathrm{K}^{+} / \mathrm{Na}^{+}$ratio in actively growing tissues. In contrast, 'Picual' was the least salt-tolerant with a similar concentration of $\mathrm{Na}^{+}$in root and leaf and the highest decrease of $\mathrm{K}^{+} / \mathrm{Na}^{+}$ratio in leaf. Furthermore, between the compatible osmolytes studied, only phenolic compounds were accumulated in 'Ocal' and 'Picual'.

\section{Literature Cited}

Ali, M.B., E.J. Hahn, and K.Y. Paek. 2005. Effects of temperature on oxidative stress defense systems, lipid peroxidation and lipooxygenasae activity in Phalaenopsis. Plant Physiol. Biochem. 43:213-223.

Arnon, D.T. 1949. Copper enzyme in isolated chloroplasts polyphenoloxidase in Beta vulgaris. Plant Physiol. 24:1-15.

Bates, L.S., R.P. Waldren, and I.D. Teare. 1973. Rapid determination of free proline water stress studies. Plant Soil 39:205-207.

Ben Ahmed, C., S. Magdich, B. Ben Rouina, S. Sensoy, M. Boukhris, and F. Ben Abdullah. 2011. Exogenous proline effects on water relations and ions contents in leaves and roots of young olive. Amino Acids 40:565-573.

Blokhina, O., E. Virolainen, and K.V. Fagestedt. 2003. Antioxidants, oxidative damage and oxygen deprivation stress: A review. Ann. Bot. (Lond.) 91:179-194.

Calero, J., M.P. Cordovilla, V. Aranda, R. Borjas, and C. Aparicio. 2013. Effect of organic agriculture and soil forming factors on soil quality and physiology of olive trees. Agroecol. Sustain. Food Syst. 37:193-214.

Chartzoulakis, K., M. Loupassaki, M. Bertaki, and I. Androulakis. 2002. Effects of $\mathrm{NaCl}$ salinity on growth, ion content and $\mathrm{CO}_{2}$ assimilation rate of six olive cultivars. Sci. Hort. 96:235247.

Chartzoulakis, K.S. 2005. Salinity and olive: Growth, salt tolerance, photosynthesis and yield. Agr. Water Mgt. 78:108-121.

Cordovilla, M.P., M. Bueno, C. Aparicio, and M. Urrestarazu. 2014. Effects of salinity and the interaction between Thymus vulgaris and Lavandula angustifolia on growth, ethylene production and essential oil contents. J. Plant Nutr. 37:875-888.

Demiral, M.A. 2005. Comparative response of two olive (Olea europaea L.) cultivars to salinity. Turk. J. Agr. For. 29:267-274.

Ellman, G.L. 1959. Tissue sulphydryl groups. Arch. Biochem. Biophys. 82:70-77.

Hoagland, D.R. and S. Arnon. 1950. The water culture method for growing plants without soil. Calif. A.E.S. Bull. 374:1-39.

International Olive Oil Council. 2003. The world olive oil market. Olivae 97:19-21.

Iqbal, N., S. Umar, N.A. Khan, and M.I.R. Khan. 2014. A new perspective of phytohormones in salinity tolerance: Regulation of proline metabolism. Environ. Expt. Bot. 100:34-42.

Irigoyen, J.J., D.V. Emerich, and M. Sanchez-Díaz. 1992. Water stress induced changes in concentration of proline and total soluble sugars in nodulated alfalfa (Medicago sativa). Physiol. Plant. 84:55-60.

Kchaou, H., A. Larbi, M. Chaieb, R. Sagardoy, M. Msallem, and F. Morales. 2013. Genotypic differentiation in the stomatal response to salinity and contrasting photosynthetic and photoprotection responses in five olive (Olea europaea L.) cultivars. Sci. Hort. 160:129138.
Loreto, F., M. Centrito, and K. Chartzoulakis. 2003. Photosynthetic limitations in olive cultivars with different sensitivity to salt stress. Plant Cell Environ. 26:595-601.

Melgar, J.C., J.P. Syvertsen, and F. García-Sánchez. 2008. Can elevated $\mathrm{CO}_{2}$ improve salt tolerance in olive trees? J. Plant Physiol. 165:631-640.

Munns, R. and M. Tester. 2008. Mechanisms of salinity tolerance. Annu. Rev. Plant Biol. 59: 651-681.

Remorini, D., J.C. Melgar, L. Guidi, E. Delg'Innocenti, S. Castelli, M.L. Traversi, R. Massai, and M. Tattini. 2009. Interaction effects of root-zone salinity and solar irradiance on the physiology and biochemistry of Olea europaea. Environ. Expt. Bot. 65:210-219.

Rosen, H. 1957. A modified ninhydrin colorimetric analysis for amino acids. Arch. Biochem. Biophys. 67:10-15.

Singleton, V.L. and J.A. Rossi. 1965. Colorimetry of total phenolics with phosphomolybdicphosphotungstic and acid reagents. Amer. J. Enol. Viticult. 16:144-158.

Tattini, M., R. Gucci, M.A. Coradeschi, C. Ponzio, and J.D. Everard. 1995. Growth, gas exchange and ion content in Olea europaea plants during salinity stress and subsequent relief. Physiol. Plant. 95:203-210.

Turan, S. and B.C. Tripathy. 2012. Salt and genotype impact on antioxidative enzymes and lipid peroxidation in two rice cultivars during deetiolation. Protoplasma 250:209-222.

Weissbein, S., Z. Wiesman, Y. Ephrath, and M. Silberbush. 2008. Vegetative and reproductive response of olive cultivars to moderate saline water irrigation. HortScience 43:320-327.

Wellburn, A.R. 1994. The spectral determination of chlorophylls a and b, as well as total carotenoids, using various solvents with spectrophotometers of different resolution. Plant Physiol. 144:307-313.

Yazici, I., I. Türkan, A.H. Sekmen, and T. Demiral. 2008. Salinity tolerance of purslane (Portulaca oleracea L.) is achieved by enhanced antioxidantive system, lower level of lipid peroxidation and proline accumulation. Environ. Expt. Bot. 61:49-57. 